\title{
The Order of Christian Theology: Literal and Ecclesial Senses of the New Testament
}

\author{
T.J. Lang, University of St Andrews \\ tjl5@st-andrews.ac.uk
}

\begin{abstract}
This article aims to clarify, from perspective of New Testament interpretation, (1) what it is one develops in theological interpretation of the New Testament, or literal senses of the New Testament; and (2) what it is that results from this theological work, or ecclesial senses of the New Testament. According to such a schema, theological interpretation of the New Testament is analogous to Christian allegorical interpretation of the Old. Both involve a retrospective reinterpretation of scriptural traditions informed by newly determinative realities of the present. The remaining question is how a distinction between literal and ecclesial senses of the New Testament addresses the relation of scripture and dogma. Given certain facts of the canonical formation of the New Testament, this question is as much historical as it is theological because, historically and theologically, the New Testament canon and its theological interpretation are intertwined and mutually determinative.
\end{abstract}

\section{Introduction}

Nuance is not always an analytic virtue. ${ }^{1}$ Sometimes, in service of certain intellectual ends, it is necessary to simplify an otherwise multifaceted reality. I begin by reducing the complex history of early Christian biblical exegesis to a single dilemma: how to hold together the new revelation of God in Christ with the antecedent revelation of God in Jewish scripture?

Perched betwixt two forms of exegetical literalism - the literalism of ongoing Judaism, on the one hand, which maintains Torah observance as its systemic core, and the literalism represented by Marcion, on the other, which jettisons the Old Testament altogether-most

\footnotetext{
${ }^{1}$ I direct the reader to Kieran Healy's impishly titled but theoretically serious essay, "Fuck Nuance," Sociological Theory 35 (2017): 118-27. Although Healy's argument is about the proper place of nuance within sociological theory, his insights on the necessity of abstraction for large-scale theoretical work are transferable.
} 
early Christians chose instead a non-literal way. ${ }^{2}$ This was the way of allegory. Other terms of art would be used to describe Christian allegorical interpretation, but "allegory" was the

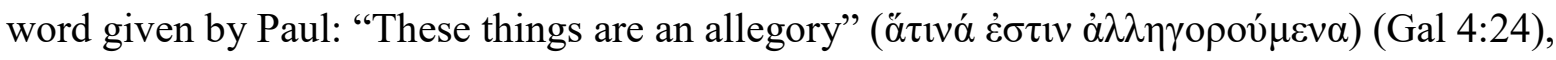
says Paul of his revisionary rereading of Sarah and Hagar as a story of two covenants corresponding to two Jerusalems (and a few other binaries, as well). Impressed by Paul's ecclesially determined allegoresis of Jewish scriptures, subsequent Christians took Paul's exegetical models as mandates to go and do likewise. ${ }^{3}$ And they did, hermeneutically transforming sacred Judean writings into the Christian Old Testament.

\footnotetext{
${ }^{2}$ My use of the word "literalism" is not pejorative. With respect to ancient Judaism, literalism refers to the conventional terms within which Jewish scriptures were read, which is to say, with Torah observance as the lived plausibility structure within which the words of scripture make sense. Alternatively, the exegetical literalism represented by Marcion is diagnosed by Sebastian Moll: "Marcion did not understand the Old Testament in the light of the New, he interpreted the New Testament in the light of the Old.... This is why it would be a misconception to believe that Marcion would have needed the New Testament in order to 'discredit' the Old, for it is in fact the Old Testament which forms his starting point" (The Arch-Heretic Marcion, WUNT 250 [Tübingen: Mohr Siebeck, 2010], 82).

3 “Ecclesially determined” echoes Richard B. Hays's influential characterization of Pauline hermeneutics in Echoes of Scripture in the Letters of Paul (New Haven, CT: Yale University Press, 1989). Hays describes Paul's general exegetical approach as "ecclesiocentric" and reads Gal 4:21-23 as evidence of "the unexpected working of this ecclesiocentric hermeneutic" (86). The key observation is that Paul does not identify Abraham's seed with Christ but instead "reads Isaac as a prefiguration of the church" (86).
} 
Although the two Testaments come to be regarded by Christians as a unified entity, on the matter of allegory they have not been regarded as equivalent. Whereas the "letter" of the Old Testament is treated as full of cryptic allegories, mysteries, types, signs, parables, enigmas, and figures in need of allegorical unlocking, the New Testament is seen as supplying the master key to do just this. As Robert Louis Wilken explains, "In its original sense, Christian allegory as an interpretive technique is a way of interpreting the Old Testament in light of the new things that have taken place with the coming of Christ. The New Testament does not need an allegorical interpretation because it speaks directly about Christ.... The spiritual meaning of the New Testament events is the literal meaning." As one medieval interpreter put the matter: "[The New Testament] is to be interpreted as it is heard. It does not require allegory" (Pro se [New Testament] stat sicut auditor; non est allegoria) ${ }^{5}$ As Augustine formulated a similar principal centuries prior: "If a reading is already clear literally (proprie), then a figurative expression (figurata) need not be considered" (De Doc. 3.15.23).

What such statements imply is an essential difference in the natures of the Old and New Testaments. Origen is one early representative of such an understanding. As he explains in his Commentary on John, Israel's scriptures were not knowable as "gospel" prior to the

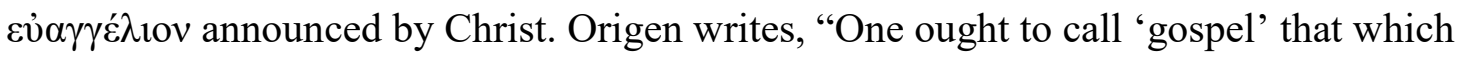
generated what we regard as gospel in the Old Testament, but 'gospel' in a special sense

\footnotetext{
${ }^{4}$ Robert Louis Wilken, “In Defense of Allegory,” Modern Theology 14 (1998): 197-212, here 201.

${ }^{5}$ Cited by Wilken, “In Defense of Allegory,” 201, who is himself citing de Lubac (see p. 211 n. 9 for bibliography).
} 
('் $\xi \alpha \iota \varepsilon \dot{\tau} \tau \varsigma)$ )." According to Origen's reasoning, insofar as the gospel in the New Testament

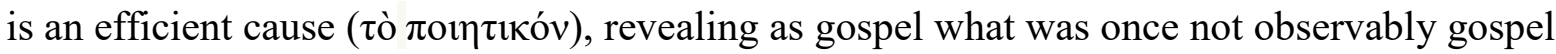
in the Old Testament, the two Testaments cannot be equated. The New Testament gospel is "gospel" in a special sense. ${ }^{7}$ Henri de Lubac similarly develops this distinction between the Testaments. Reprising a long tradition, de Lubac takes Paul's "letter" $(\gamma \rho \alpha ́ \mu \mu \alpha)$ and "Spirit" $(\pi v \varepsilon \tilde{v} \mu \alpha)$ contrast (e.g. 2 Cor 3:6) as paradigmatic for the canon as a whole. The Old Testament is the "letter" for which the New Testament is its complementary allegorical "Spirit." The inference following from this is that one should not allegorically interpret what is already an allegorical interpretation. De Lubac explains, "When we ask whether the New Testament has, like the Old, an allegorical meaning, this seems to come down to asking if... an allegorical commentary must be made on an allegorical commentary. But how could such a question be answered except in the negative." 8

This argument is plain enough. But there is an additional complexity in Christian thinking about the nature of New Testament interpretation. And by complexity, I mean fact. The reality is that numerous central dogmas of Christian theology— the trinity being foremost — are confessed as based on New Testament teaching when in fact they are not to be

\footnotetext{
${ }^{6}$ Origen, Commentary on John 1.6.36.

${ }^{7}$ It would be wrong to read into Origen's words something like a Lutheran law/gospel contrast. Origen's emphasis is on that which is latent in the Old Testament and then made manifest through the hermeneutical lens of Christ's advent. For an even clearer programmatic statement regarding how the "spiritual" nature of Israel's scriptures only comes to light after the advent of Christ, see e.g. On First Principles 4.1.6.

${ }^{8}$ This passage is available in English translation in Henri de Lubac, The Sources of Revelation, trans. Luke O’Neill (New York, NY: Herder \& Herder, 1968), 198.
} 
found in the New Testament in any plain or literal way. This is the question of doctrinal development: How do we articulate and defend the authority of later dogmatic teachings that claim to be interpretations of the New Testament but also clearly exceed what the New Testament explicitly says? One common and, indeed, ancient solution to this question is to view the "letter" of the New Testament as communicating conceptualities implicit or inchoate in the scriptural syntax. Dogmatic development is thus the deduction of inherent or embryonic scriptural realities. To return once more to Origen, we glimpse something of this in the introduction to On First Principles, where he distinguishes "The kind of doctrines which are believed in plain terms through apostolic teaching" (1.4) from doctrines that have not been clearly defined in Christian teaching but which, nonetheless, "follow logically [from other conclusions] when rightly understood" $(1.10) .{ }^{9}$

The structure of such reasoning is uncomplicated: On the one hand, there are teachings plainly taught; on the other, there are teachings discerned by inference, deducing propositions from other clearer propositions. Such is the logical development of doctrine. ${ }^{10}$ There are, to be sure, severe limitations to an overly "rationalist" construal of doctrinal

\footnotetext{
${ }^{9}$ This is the translation of G.W. Butterworth, Origen: On First Principles (Gloucester, MA: Peter Smith, 1973).

${ }^{10}$ Sustained interest in doctrinal development is admittedly mostly a modern preoccupation, with roots in $19^{\text {th }}$-centruy scholars such as Johann Adam Möhler and John Henry Newman. The most noteworthy ancient theorist of development is the fifth-century theologian Vincent of Lérins in his Commonitorium. See esp. Thomas G. Guarino, Vincent of Lérins and the Development of Christian Doctrine (Grand Rapids, MI: Baker, 2013); idem, “Tradition and Doctrinal Development: Can Vincent of Lérins Still Teach the Church?," Theological Studies
} 67 (2006): 34-72. 
development, as there are to other (e.g. so-called "vitalist" or "organic") conceptions, and qualifications must always be added, as they must always be added. ${ }^{11}$ Let us pretend that development works this neatly. ${ }^{12}$ (It doesn't.) The process of development is not the primary interest of this essay. My aim is instead to clarify, from perspective of New Testament interpretation, the relation of interpretive theological extensions of New Testament teaching to matters of ecclesial concern with forms of interpretation demarcated by strictly historical or literary interests. I refer to the former-the ecclesially oriented theological development of New Testament material—as ecclesial senses of the New Testament, and the latter-the interpretation of individual New Testament texts on their own historical or literary terms (and independent of their canonical frame) — as literal senses of the New Testament. ${ }^{13}$ Such a

\footnotetext{
${ }^{11}$ Still relevant to these matters is Henri de Lubac's discerning essay, “The Problem of the Development of Dogma," in Theology in History, trans. Anne Englund Nash (San Francisco,
} CA: Ignatius, 1996), 248-80. For a lucid account of the shortcomings of logical and organic accounts of development, see Kathryn Tanner, "Postmodern Challenges to 'Tradition'," Louvain Studies 28 (2003): 175-93.

${ }^{12}$ An alternative to viewing doctrinal development as simply a matter of logical deduction is David S. Yeago, “The New Testament and the Nicene Dogma: A Contribution to the Recovery of Theological Exegesis," Pro Ecclesia 3 (1994): 152-64. Yeago contends that a doctrine like the Nicene homoousion "is neither imposed on the New Testament texts, nor distantly deduced from the texts, but rather describes a pattern of judgment in the texts" $(153)$.

${ }^{13}$ Nuance is, of course, needed here (despite the recommendation in n. 1). Under the category of the "literal" I would include both historical-critical approaches, which disregard the canonical framing of a given New Testament text (and perhaps even the "final form" of a 
schema situates ecclesial interpretation of the New Testament as analogous to (but not identical to!) Christian allegorical interpretation of the Old. Both approaches to the two Testaments involve a retrospective reinterpretation of scriptural traditions informed by newly determinative realities in the present. Both allow the meaning of texts to unfold in time vis-àvis ever new horizons. Neither need disregard the potential meanings of a text in its moment of production, redactional history, or subsequently determined canonical frame (or longue durée of interpretive history). Ecclesial senses instead appropriate and extend those meanings — or dialogically engage those meanings — to address new questions and concerns, or in light of new facts. ${ }^{14}$

I begin by exploring two precursors to this distinction between literal and ecclesial readings of the New Testament. The first, from late antiquity, is Gregory of Nazianus's Fifth Theological Oration (Or. 31). The second, from more recent times, is an essay by the young Joseph Ratzinger. To conclude, I further develop my own thinking about this distinction between literal and ecclesial interpretations of the New Testament and the analogous relation

purportedly redacted Gospel or partitioned letter), and also literary approaches, which might approach a New Testament text within the context of the total canon but do not seek to extend theological ideas or address concerns a text does not itself address; they thus limit themselves to description alone.

${ }^{14}$ A comparable expression of the type of dialogical engagement and extension I am envisioning is developed vis-à-vis Jewish exegesis by Benjamin D. Sommer, "Dialogical Biblical Theology: A Jewish Approach to Reading Scripture Theologically," in Biblical Theology: Introducing the Conversation, ed. Leo G. Perdue, Robert Morgan, and Benjamin D. Sommer (Nashville, TN: Abingdon Press, 2009), 1-53. 
of ecclesial interpretation of the New Testament to Christian allegorical interpretation of the Old Testament via a recent response to Richard Hays's Echoes of Scripture in the Gospels. ${ }^{15}$

\section{Pneumatology and the "Order of Theology" according to Gregory of}

\section{Nazianzus}

There is no need to dwell on the specific personages under attack in Gregory's Fifth Theological Oration (Or. 31) or on their broader theological profiles. ${ }^{16}$ Simply put, Gregory's quarrel in this work is with those who deny the Spirit's divinity and thus the standing of the Spirit in the doctrine of God. The charge hurled against Gregory is that of innovation. Gregory's opponents maintain that his trinitarian commitment to the Holy Spirit as consubstantial (ómoov́øiov) ${ }^{17}$ with the Father and the Son "imports some strange and interpolated god" (Or. 31.3) and is without any scriptural basis. It is ö $\gamma \rho \alpha \varphi \varsigma$, an unscriptural claim, they allege (Or. 31.1). ${ }^{18}$ As Gregory's opponents see it, the terms of the dispute are not

${ }^{15}$ Richard B. Hays, Echoes of Scripture in the Gospels (Waco, TX: Baylor University Press, 2016).

${ }^{16}$ For all matters related to this oration and its interpretation, see Christopher A. Beeley, Gregory of Nazianzus on the Trinity and the Knowledge of God: In Your Light We Shall See Light (Oxford: Oxford University Press, 2008), 153-86; Frederick W. Norris, Faith Gives Fullness to Reasoning: The Five Theological Orations of Gregory Nazianzen (Leiden: Brill, 1991), 183-213.

${ }^{17}$ See Or. 31.10.

${ }^{18}$ At the outset of the oration Gregory presents his opponents as asking: "From where do you

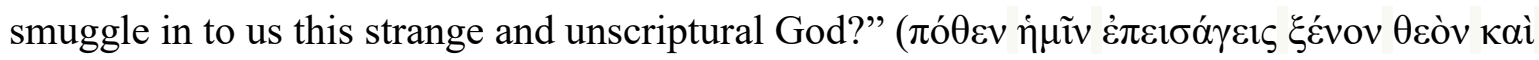

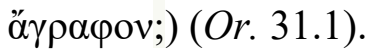


primarily philosophical or theological, but exegetical. Does the New Testament, rightly read, teach the divinity of the Holy Spirit, or does it not? Gregory's opponents insist it does not. As Gregory eventually acknowledges, his opponents indeed have a certain silence on their side. But this is where the qualification "rightly read" makes all the difference.

As the texts Gregory later adduces in support of his position make clear (Or. 31.2930), the interpretive debate in the Fifth Oration concerns the New Testament specifically, a textual field both parties regard as authoritative for theological thinking. In this sense, the dispute over the divinity of the Spirit in the New Testament mirrors exegetical debates between Jews and Christians over the question of Christ in the Old Testament. Both sides agree on the textual grounds upon which the matter is to be settled. Where they clash is on the appropriate hermeneutical posture required to read those texts rightly. In the case of Christ in the Old Testament, the divergence is usually expressed in terms of "literal" versus "spiritual" or "allegorical" interpretive approaches. As Gregory turns in the Fifth Oration to the question of the Spirit's divinity, and the New Testament witness to it, it is important to notice how he adopts the "literal" versus "spiritual" categories of Old Testament interpretation, but now applies them to the New. ${ }^{19}$ Gregory chides his opposition for their excessive "love for the letter" (Or. 31.3) and reprimands them for not "penetrating the letter and peering into the inner meaning" (Or. 31.21). In so doing the reader begins "to see the hidden beauty" of the New Testament teaching (Or. 31.21). He asks of his opponents, "Why are you thus such a slave to the letter, and a devotee of Jewish wisdom, and a follower of

\footnotetext{
${ }^{19}$ So also Norris notes that Gregory's exegetical case for the divinity of the Spirit "suggests reliance on allegorical exegesis" (Faith Gives Fullness to Reasoning, 203). In the end, however, Norris concludes allegory is perhaps not the best category for describing Gregory's approach (203-4).
} 
syllables, while jettisoning facts?" (Or. 31.24). Note the effect of this rhetoric: By aligning his adversaries with Jewish readers of the Old Testament, who also fail to "penetrate the letter," he insinuates that their reading of the New Testament is similarly deficient. They cling to the literal and so fail to perceive the spiritual. In this case, the spiritual meaning they fail to perceive is the New Testament's oblique witness to Holy Spirit's divine identity. But note the critical concession: Gregory is acknowledging that his own judgments about the Spirit do not reside on the literal sense of the text but somehow beneath or within it, in its "inner meaning." He even admits that the Spirit "is not very clearly described by scripture as God, nor as such by name, as is the Father first and subsequently the Son" (Or. 31.21). Gregory's pneumatological claims are indeed, by his own admission, in some sense ö $\gamma \rho \alpha \varphi \varsigma$ (Or. 31.29). On the surface of the letter of the New Testament, a consubstantial Spirit is not to be found.

How then does Gregory align the New Testament with his trinitarian convictions? He first appeals to a distinction between sense and reference. Just as "twice five" corresponds to "ten," or "a rational and mortal animal" to a "human," so one must distinguish between the diverse signs used to express something and that "something," or referent, to which the signs point. In the case of the Spirit, more important than the explicit terms used to name the Spirit's identity are the implicit meanings conveyed through the New Testament's syntax (Or. 31.24). The faithful reader must do the work of expounding the signification "of things not said, or at least not said plainly" (Or. 31.24). Hence when it comes to trinitarian pneumatology in the New Testament, it is on the level of the inferable that the "hidden beauty" is to be found.

This is a standard developmental argument. More theologically adventurous is Gregory's subsequent explanation for why knowledge of the trinity is unfolded in this way. He does this by sketching a comprehensive account of theological development extending 
from historical Israel to the era of the church. In a disclosure elongated across time, the identity of Israel's God is gradually revealed as Father, then Son, and finally Holy Spirit, the revelation of each according to a respective era. ${ }^{20}$ As a theory of development, Christopher Beeley warns that Gregory "has often been misunderstood." Gregory is not, in Beeley's view, "making a statement of progressive doctrinal development through the history of the Church, as in the nineteenth-century views of Schleiermacher and Newman." ${ }^{21}$ This is true. What Gregory proposes is certainly not like that of Schleiermacher and Newman. But it is nonetheless still a theory of development, in this case the development of the trinity, and it is one that has profound implications for conceiving the relation of trinitarian theology and ecclesial tradition to biblical exegesis in the post-Pentecost, ecclesial context. ${ }^{22}$

To return to Gregory. Again, his primary burden is to explain the reason for the "secrecy" of the New Testament with respect to the divinity and consubstantiality of the Spirit. He does not in any way admit the New Testament is devoid of trinitarian

${ }^{20}$ For an earlier variety of this view, see Tertullian, Against Praxeas, 31.

${ }^{21}$ Beeley, Gregory of Nazianzus, 169.

${ }^{22}$ As Joseph W. Trigg remarks, “Gregory’s theology thus makes possible the recognition of real change in doctrine... Thus, long before Schleiermacher or Newman, Gregory argues for progressive change, if not organic development in the $19^{\text {th }}$ century sense, in the church's doctrine.... For Gregory....as for Origen, the church's understanding of God is not something perfect and static, given for all time, but a dynamic process by no means complete" ("Knowing God in the Theological Orations of Gregory of Nazianzus: The Heritage of Origen," in God in Early Christian Thought: Essays in Memory of Lloyd G. Patterson, ed. Andrew B. McGowan, Brian E. Daley, and Timothy J. Gaden [Leiden/Boston, MA: Brill, 2009], 83-104, here 103-4). 
pneumatology. He insists that this teaching is present "in the letter," but in a concealed

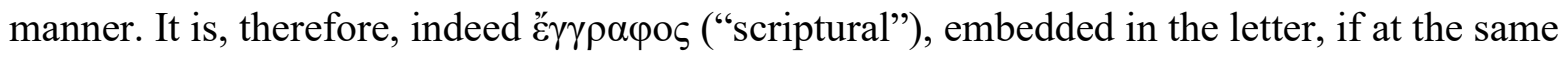
time ö $\gamma \rho \alpha \varphi \circ \varsigma$ ("unstated") in terms of explicit reference. ${ }^{23}$ But if truly है $\gamma \gamma \rho \alpha \varphi \circ \varsigma$ in this embedded sense, why is it concealed in the first place? This, Gregory maintains, is in keeping with God's plan for the progressive unfolding of the trinity at large- - from theology, to christology, to pneumatology. This unfolding extends across the two Testaments and into the church's post-Pentecost life. In one of the more stunning moments in patristic literature, Gregory writes:

There have been, from the entirety of existence, two conspicuous "transpositions" $(\mu \varepsilon \tau \alpha \theta \varepsilon ́ \sigma \varepsilon 1 \varsigma)^{24}$ in human lives, which are also called two Testaments, or, on account of the fame of the matter, two earthquakes; the one from idols to the law, and the other from the law to the gospel. And of a third earthquake we have received good news ( $\varepsilon \dot{\alpha} \alpha \gamma \varepsilon \lambda \lambda_{\imath} \zeta \operatorname{ó} \mu \varepsilon \theta \alpha$ ), namely, from this earth to that which cannot be shaken or moved $(\sigma \alpha \lambda \varepsilon v o ́ \mu \varepsilon v \alpha){ }^{25}$

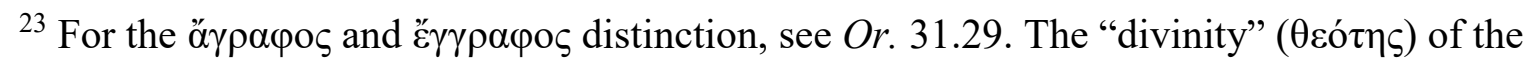
spirit is $\alpha$ orpapos in that it is not explicitly identified on the surface of the letter, but it is found

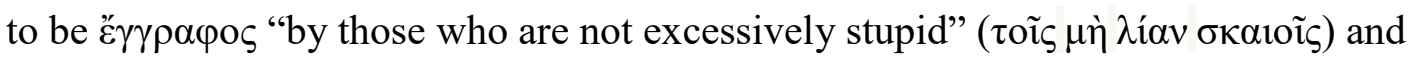

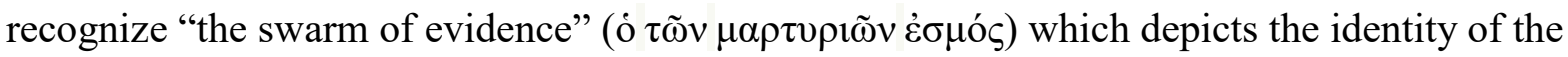
Spirit as integral to that of the Father and the Son (31.29). Again, this "swarm of evidence" is visible only to readers "penetrating the letter and peering into the inner meaning" of New Testament teaching (Or. 31.21).

${ }^{24}$ The choice of this word evokes Heb 12:26-28.

${ }^{25} \mathrm{Or} .31 .25$. For the likely influence of Origen on this passage and Gregory’s understanding of pedagogical progress in theology more generally, see Trigg, "Knowing God," 83-104. 
Gregory goes on to coordinate these three earthquakes with the progressive disclosure of trinitarian doctrine. In Gregory's schema, the "earthquake" of the Old Testament announced the Father "plainly" but the Son only "obliquely" (Or. 31.26). The New Testament then explicitly manifested the Son and his divinity, but only hinted at that of the Spirit. Next comes Gregory’s third earthquake, inaugurated at Pentecost. ${ }^{26}$ It is with the third earthquake that the full identity of the Godhead is revealed with clarity. Gregory writes, "Now the Spirit himself dwells among us, and supplies us with a clearer demonstration of himself' (Or.

31.26). Therefore, while the Old and New Testaments provide textual witnesses to the divine identities of the Father and Son respectively, the divinity of the Spirit is revealed experientially in the church's gathering. The church (and even the individual Christian) is the divine Spirit's documentation. ${ }^{27}$

\footnotetext{
${ }^{26}$ I say “inaugurated” because in Or. 21.25 Gregory identifies Christ's second coming

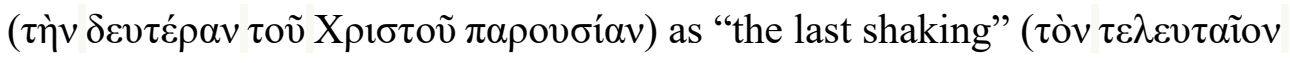

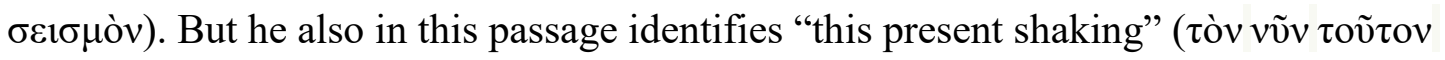
$\sigma \varepsilon ı \sigma \mu o ̀ v)$ — the shaking inaugurated in Pentecost — as the era in which believers "proleptically

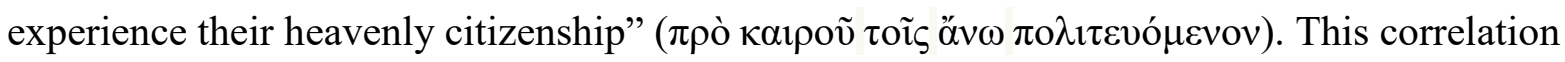
of a "present shaking" with a "last shaking" in Or. 21.25 corresponds to Gregory's description of the third earthquake as "from this earth to that which cannot be shaken or moved" in Or. 31.25. The "present shaking" thus awaits eschatological consummation in the "last shaking."

${ }^{27}$ Norris helpfully identifies this dynamic and its relation to Gregory's strong commitment to scriptural revelation. He identifies Gregory as going beyond his precursors in understanding "the fullest revelation of the Spirit outside the Scriptures as a necessary and fulfilling inference from what had gone before" (Faith Gives Fullness to Reasoning, 206). Gregory 
It is important to emphasize the ecclesial setting of the Spirit's era, which Gregory elsewhere explicitly aligns with Pentecost. We see this alignment unambiguously with his reference to "tongues of fire" and Christ's ascension in his poem on the Spirit, wherein he again lays out his comprehensive schema for the unfolding of trinitarian doctrine:

For, just as in former times teaching brought to light the full Godhead of the sovereign Father, while enlightening only a few wise mortals by showing the great glory of Christ, so later, when revealing more clearly the Godhead of the Son, it manifested only half-hidden gleams of the shining Spirit's Godhead. Gradually the Spirit began to shine for these people, but he reserved the greater part for us, for whom in later times he has divided in tongues of fire, bringing a token of his divinity when the Saviour had leapt up from the earth.... This is how I sum up for you the case for Godhead. ${ }^{28}$

thus views "“extra-Biblical' tradition as part of the important gift to the contemporary church" (206). Nonetheless, "Gregory would never view such traditions in a Protestant sense of "extra-Biblical"” (207). Rather, "Christian tradition...is formed of Scripture and church practice" (207). Even so, "no fair historian or theologian can question Cappadocian dependence upon Scripture.... Indeed the Theologian sees himself on strong Scriptural grounds. He senses that he is only drawing out an inference from the way revelation is portrayed in the Bible. Yet his claim opens up the use of concepts, words and perhaps doctrines 'not mentioned in Scripture"” (207).

${ }^{28}$ This translation is from D.A. Sykes, ed. and trans., St Gregory of Nazianzus: Poemata Arcana (Oxford: Clarendon Press, 1997), 10-13. 
This "greater part" of the Spirit's revelation is the revelation of the Spirit's place in the doctrine of God. In the economy of the trinity's disclosure, this revelation was tangibly first encountered in Pentecost's tongues of fire.

Gregory again associates the special disclosure of the Spirit with Pentecost in his oration on that feast (Or. 41.5):

But first the Spirit appeared obscurely $(\dot{\alpha} \mu v \delta \rho \tilde{\omega} \varsigma)$, and second more distinctly in

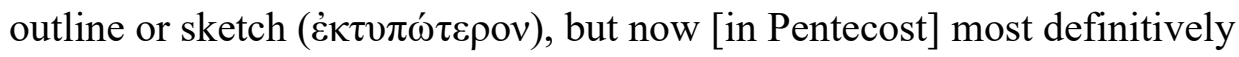

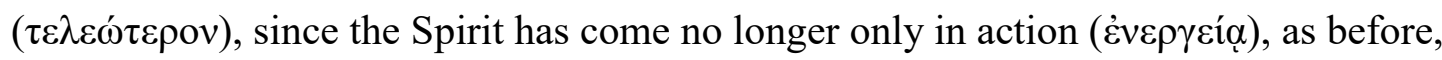

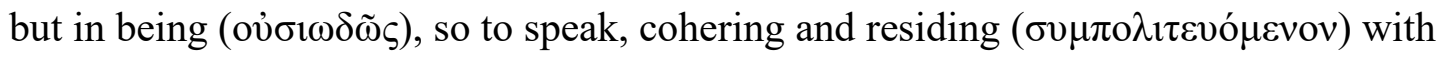
us. For it was fitting that as the Son joined us bodily ( $\sigma \omega \mu \alpha \tau 1 \kappa \tilde{\omega} \varsigma)$, so too the Spirit should be revealed bodily ( $\varphi \alpha v \tilde{\eta} v \alpha \iota$ $\sigma \omega \mu \alpha \tau 1 \kappa \tilde{\omega} \varsigma)$; and that after Christ had returned to his own place, it should have come down to us.

The bodily presence of the Spirit within the church is crucial to Gregory's argument. It draws Pentecost in parallel with Christ's incarnation, both of which represent the definitive revelations of the second and third members of the trinity respectively. There is, however, an interesting difference between Christ's incarnation and the presence of the Spirit within the church. Whereas Christ, both in his incarnation and the New Testament witness to him, is discerned thorough observation, the Spirit is revealed to believers by personal embodiment. God is thus again revealed "in being," but now by indwelling individual believers. The deity of the Spirit is, as Paul might say, "written on your hearts" (2 Cor 3:3). Believers thus become living "testaments" of trinitarian dogma, "written not with ink but with the Spirit of the living God, not on tablets of stone but on the tablets of human hearts" (2 Cor 3:4).

It is important now to examine Gregory's understanding of the reason for this gradual unfolding of God's trinitarian identity_ "the reason for the entire system of concealment" (Or. 31.24). For Gregory, the trinity is an overpowering truth. God therefore slowly unveils it 
like a wise pedagogue, patiently moving humanity into truth bit by bit, with steady persuasion and gradual moral reform (Or. 31.25). "You see the light shining forth

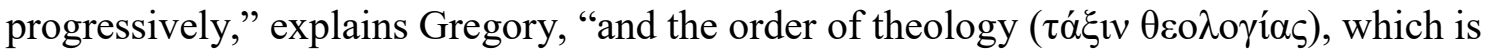
better for us to keep, not illuming things all at once, but not keeping them concealed until the end. The former would be unfitting; the latter contrary to God; the former would overwhelm outsiders; the latter would estrange our own" (Or. 31.27). God thus moves closer to humanity in stages, first in the revelation of the Father, then in the incarnation of the Son, and finally through the personal embodiment of the Spirit. This, according to Gregory, is the "order of theology" ( $\tau \alpha \dot{\xi} \xi \varsigma \theta \varepsilon o \lambda o \gamma i ́ \alpha \varsigma)$.

Importantly, Gregory insists this "order of theology" is not his own invention. It was intimated by Jesus himself.

The Savior had some teachings which his disciples, being filled with many things, were not able to bear in mind ( $\beta \alpha \sigma \tau \alpha \chi \theta \tilde{\eta} v \alpha \imath)$ (perhaps for the reasons I have mentioned), and so they were concealed. And again, he said that all things should be taught to us by the Spirit when it comes to dwell in us. Of these things, one I believe is the very deity of the Spirit, which was clarified only afterwards, at just the appropriate time for this knowledge... and when it would not be disbelieved on account of its astonishing nature. ${ }^{29}$

Gregory is here recalling a few Johannine passages concerning the coming Paraclete (e.g. John 14:25-26) and, in particular, John 16:12-13, where Jesus explains that he has much to impart to his disciples, but they are not yet able "to bear" such teaching (ov̉ $\delta v ́ v \alpha \sigma \theta \varepsilon$

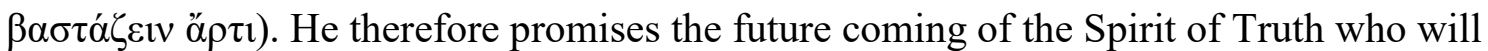

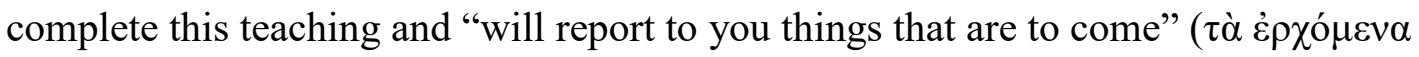

${ }^{29}$ Or. 31.27. 
$\dot{\alpha} v \alpha \gamma \gamma \varepsilon \lambda \varepsilon \tilde{\imath} \dot{v} \mu \tilde{\imath} v)$. This idea that there are truths about which even Jesus's closest companions were not fit to entertain during the course of his earthly sojourn, and that the Spirit will induct the church into these truths after Jesus has departed, fits perfectly with Gregory's understanding of theology's sequence. But there remains the question: What does this order of theology mean for interpretation, especially the interpretation of the New Testament?

When Gregory arrives at his interpretation of the Spirit in the New Testament, it is critical to observe how he relates his theological conclusions to the New Testament evidence. Gregory does not form his judgment about the divinity of the Spirit of the basis of straightforward textual interpretation. He comes to his conclusion, first, by interpreting himself. Gregory insists that when the Christian perceives what the Spirit has done in her life, she can only conclude that God has done this. And, with this insight, the divinity of the Spirit once concealed in the New Testament now "seizes" the reader of it: ${ }^{30}$

And from the Spirit comes new birth; from the new birth, new creation; from the new creation, knowledge of the true esteem of the one who recreates. These things, then,

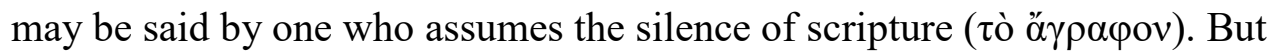
immediately the swarm of scriptural testimonies seizes you, from which, because it is

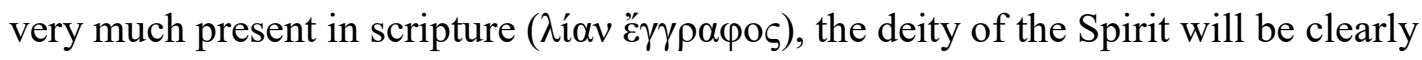
demonstrated..$^{31}$

\footnotetext{
${ }^{30}$ It is instructive to compare Gregory's argument for the Spirit's divinity to the very different approach of his friend Basil, who appeals to secret (extra-scriptural) apostolic tradition. See R.P.C. Hanson, "Basil's Doctrine of Tradition in Relation to the Holy Spirit," Vigiliae Christianae 22 (1968): 241-55.

${ }^{31}$ Or. 31.28-29.
} 
For Gregory, what I have termed the ecclesial sense of the New Testament emerges from the retrospective interpretation of the New Testament in light of the facts of Christian experience - the experience of the Spirit in Pentecost and Christian baptism being foremost. As Beeley explains, "The confession of the Spirit's divinity — and in many ways the whole enterprise of Christian theology — is thus the result of the Spirit's direct and immediate work in the life of the Church.... The indwelling of the Holy Spirit is thus the epistemic principle of all knowledge of God in Christ." 32 Note that the chain of theological reasoning is not temporally prospective from Father to Son to Spirit but rather the reverse. From the Spirit, the Christian fully perceives the Son, and from the Son fully the Father, and so the Godhead in its trinitarian completeness. ${ }^{33}$ The Holy Spirit is thus the font of all Christian theological thinking. And the same is true when it comes to New Testament interpretation. The Spirit provides the epistemic basis from which the letter of the New Testament yields its spiritual (or ecclesial) sense. This is not to abolish the letter; nor is it to collapse letter into spirit. The literal sense maintains its own integrity, which is why Gregory candidly admits that his trinitarian commitments cannot be derived from any straightforward literal reading of the New Testament's "mere letter." But to end with the "mere letter" is to fail to perceive the

\footnotetext{
${ }^{32}$ Beeley, Gregory of Nazianzus, 179. Cf. also the more recent work of Oliver Langworthy, who writes, "it is insufficient to consider the Spirit as a subsidiary or extension of Gregory's theological programme.... Instead, any attempt to approach his soteriology or wider Trinitarianism must take account of the extent to which the Spirit's operation in salvation forms a groundwork for his other thought" ("The Holy Spirit is Truly Holy: Gregory of Nazianzus' Soteriological Pneumatology” [PhD diss., University of St Andrews, 2016], 230) Langworthy's work is currently forthcoming with Mohr Siebeck.

${ }^{33}$ Cf. Beeley, Gregory of Nazianzus, 180.
} 
truly divine Spirit within it. And it is to fail to think according to the Christian order of theology. Those who have the Spirit dwelling within them will discern that the Spirit of God described in the New Testament is indeed God as such, the God who abides in them. The ecclesial experiences of Pentecost and baptism thus generate this new hermeneutical potential, spiritually equipping the reader of the New Testament to unseal its literal sense and so discover its spiritual (which is to say, dogmatic) meaning. ${ }^{34}$

\section{An Ecclesial Theology of the New Testament}

At this point I zoom my analysis forward many centuries to consider, in more systematic terms, what the foregoing might mean for contemporary theological interpretation of the New Testament. To do this, I turn to a seminal essay from the early work of Joseph Ratzinger ("The Question of the Concept of Tradition: A Provisional Response"). ${ }^{35}$ The aim of

${ }^{34}$ As Beeley remarks, "It is highly significant that Gregory first establishes the basis of his Pneumatology in baptismal deification before he returns to the question of the biblical witness to the Spirit.... From the perspective of Church's faith-experience of the Holy Spirit, the Bible does indeed declare the Spirit's divinity—according to the Spirit, that is, not the letter. The exegesis of Scripture according to the Spirit means quite literally to interpret it on the basis of the presence and work of the Holy Spirit in the life of the Church and one's own life of purification and illumination" (Gregory of Nazianzus, 181).

${ }^{35}$ Joseph Ratzinger, "The Question of the Concept of Tradition: A Provisional Response" in God's Word: Scripture—Tradition—Office, ed. Peter Hünermann and Thomas Söding; trans. Henry Taylor (San Francisco, CA: Ignatius, 2008), 41-89. See also the recent interaction with this essay in Lewis Ayres, “'There's Fire in that Rain’: On Reading the Letter and Reading Allegorically," Modern Theology 28 (2012): 616-34, esp. 625-27; idem, “The Word 
Ratzinger's essay, first published in 1965, is to provide an account of how the revelation wrought in Christ, in his own person and words, remains revelatory beyond his ascension, and so even today. How precisely is Christ still revealed? To answer this, one must clarify a familiar (and notoriously knotty) nexus of relations, particularly those of ecclesial and scriptural authority. Ratzinger insists we must broaden the issue beyond the usual binary of "scripture and tradition." He maintains that the familiar "question of 'Scripture and tradition" remains insoluble so long as it is not expanded to a question of 'revelation and tradition' and thereby inserted into the larger context in which it belongs." 36 Ratzinger defines scripture as the "material principle of revelation," but the two - scripture and revelation — cannot be simply equated. On the one hand, God's revelation far exceeds the bounds of scripture, encompassing the totality of God's acts in history, including those to which scripture serves as witness. On the other hand, scripture and revelation do not automatically coincide. This is to say, "you can have Scripture without having revelation. For revelation always and only becomes a reality where there is faith." ${ }^{, 37}$ Although scripture mediates divine revelation to humanity, the human is still an essential participant in the revelatory experience. To borrow an image from Chrysostom, "just as children look at their books and do not comprehend the meaning of their letters," so too scripture may be read, and its letters even understood, but revelation may fail to occur. ${ }^{38}$ As Ratzinger himself states, "You cannot put revelation in

Answering the Word: Opening the Space of Catholic Biblical Interpretation," in Theological Theology: Essays in Honour of John B. Webster, ed. R. David Nelson, Darren Sarisky, and Justin Stratis (London: Bloomsbury, 2015), 37-53, esp. 44-48.

${ }^{36}$ Ratzinger, "The Question of the Concept of Tradition,” 50.

${ }^{37}$ Ratzinger, "The Question of the Concept of Tradition," 52.

${ }^{38}$ John Chrysostom, Homiliae in epistulum i ad Corinthias, Homily 7 (PG 61:55-56). 
your pocket like a book you carry around with you. It is a living reality that requires a living person as the locus of its presence." ${ }^{39}$ So also Paul: "spiritual things are discerned by spiritual people" (1 Cor 2:13). If, therefore, scripture is the material principle of revelation, then faith is the corresponding and necessary spiritual principle that catalyzes it.

By parsing scripture and revelation in this way, Ratzinger is able to emphasize the essential place of interpretation in the revelation process and, hence, the self-involvement of humanity with the revelation given by God. Scriptural revelation is thus irreducibly twofold: text and interpreter. It is from this twofold shape of the revelation process that Ratzinger turns next to the twofold shape of the Christian canon. It is here, in the canonical shape of the Old and New Testaments, that the twofold shape of the revelation process finds its complement. And it is here that my principal interest in Ratzinger's essay lies.

As he goes on the consider the "dual form of revelation in the Old and the New covenant," ${ }^{40}$ Ratzinger overlays on the Christian canon a fourfold hermeneutical scaffolding. Just as the first believers began to interpret the Old Testament in light of the newly determinative fact of Christ, so too subsequent Christians were obliged to interpret the newly bounded Old and New Testaments together in light of the Spirit who was poured out upon them in Pentecost. (This is all reminiscent of Gregory.) The dual structure of the Testaments thus requires both "the interpretation of the Old Testament on the basis of the Christ-event" and also "the interpretation of the Christ-event itself, on the basis of the Pneuma, and that means at the same time on the basis of the present ecclesiastical situation." ${ }^{41}$ This final

\footnotetext{
${ }^{39}$ Ratzinger, "The Question of the Concept of Tradition," 52.

${ }^{40}$ Ratzinger, "The Question of the Concept of Tradition," 58.

${ }^{41}$ Ratzinger, "The Question of the Concept of Tradition," 58.
} 
qualification - "on the basis of the present ecclesiastical situation"-is fundamental to Ratzinger's understanding of tradition and ecclesial interpretation of biblical revelation.

To understand what Ratzinger means by "the present ecclesiastical situation," we must first appraise his creative account of the church's early history. His presentation of the church's origins begins by distinguishing Jesus's proclamation of the eschatological kingdom of God in the Gospels and the subsequent ministry of the church, depicted in later parts of Acts and then the epistles. Ratzinger writes, "As the New Testament lets us see, the message of Jesus is at first an immediately eschatological message, directed toward the kingdom of God and not toward the Church. The fact that the Church exists is not in contradiction with this message, yet in the sequence of revelations of Christ it is only a secondary possibility." 42 This kingdom/church binary — and the idea of the church as only "a secondary possibility" is vital. Ratzinger reads the immediate work of the apostles after the resurrection as oriented toward the instantiation of God's reign in Israel, which is to say: the kingdom of God. We see this in the apostles's question to Jesus at the outset of Acts: "So when they had come together, they asked him, 'Lord, will you at this time restore the kingdom to Israel?", ${ }^{43}$ In response to the disciples kingdom-oriented question, Jesus surprising pivots away from Israel's kingdom with his missional mandate: "But you will receive power when the Holy Spirit has come upon you; and you will be my witnesses in Jerusalem, in all Judea and Samaria, and to the ends of the earth."44 This is the transition from kingdom to church. As the apostles embarked on this enterprise, Ratzinger points to a series of "historical promptings"

\footnotetext{
${ }^{42}$ Ratzinger, "The Question of the Concept of Tradition," 58-9.

${ }^{43}$ Acts 1:6. Notice also that, according to Acts 1:3, Jesus continued at that point to preach the kingdom of God to them.

${ }^{44}$ Acts 1:8.
} 
that "brought the original community to recognize that their efforts with Israel had finally failed and then to go out to the gentiles and, thus, to create the Church instead of the kingdom." ${ }^{25}$ This transition to the gentile mission was far more than a strategic change of tack. For Ratzinger it was instead the outworking of a new (and surprising) ecclesial identity under the guidance of the Holy Spirit. And with this reframing of ecclesial identity came also an obligation to rethink Jesus's own identity, and specifically his significance for the world beyond Israel. This obligation to rethink Jesus's identity and significance in light of the changed circumstances evinced by the Spirit is precisely why Ratzinger develops what he terms "an ecclesial interpretation of the New Testament," which functions as the pneumatological corollary to "a christological interpretation of the Old Testament." $" 46$ Both reappraise revealed tradition in light of a newly determinative disclosure. It is also from the final horizon of this ecclesial interpretation of the New Testament tradition that Ratzinger develops his fourfold layering of the whole canonical tradition.

When I say "fourfold layering of the whole canonical tradition," what I am referring to is Ratzinger's sketch of how the canonical tradition — as tradition —evolved, and how it is to be read in light of this evolution. At the base of this fourfold layering of biblical tradition is what Ratzinger terms "an Old Testament theology of the Old Testament." layer approaches the texts of the Old Testament in familiar historical-critical fashion, discovering the texts of that archive as themselves layered with traditions and variously inflected through reinterpretation in their complex compositional and redactional histories. These are the untidy, brute facts of the biblical tradition. As Ratzinger observes, "The

\footnotetext{
${ }^{45}$ Ratzinger, "The Question of the Concept of Tradition," 59.

${ }^{46}$ Ratzinger, "The Question of the Concept of Tradition," 60.

${ }^{47}$ Ratzinger, "The Question of the Concept of Tradition," 60.
} 
phenomenon of texts growing and developing in new situations, of revelation developing through a new interpretation of the old, quite substantially shapes the inner structure of the Old Testament itself." 48 Historical criticism concurs. Next in Ratzinger's sketch is "a New Testament theology of the Old Testament," which is certainly related to the prior interpretation in terms of the common analogy of faith, but it does not coincide with it in terms of key theological particulars. Instead, "it is a new interpretation, in the light of the Christ-event, which is not produced by mere historical reflection on the Old Testament alone." ${ }^{\prime 9}$ This new, retrospective reinterpretation of the Old in light of the New is not, Ratzinger insists, a betrayal of the antecedent tradition, nor an imposition of something foreign upon it; "rather, it is continuing the inner structure of the Old Testament, which itself lives and grows through such reinterpretations. ${ }^{50}$ Representative of this second interpretive layer are Christ's own explications of himself "in all the scriptures" (Luke 24:27). Following from this "New Testament theology of the Old Testament" is, third, "a New Testament theology of the New Testament," which complements the "Old Testament theology of the Old Testament." Here again enters the historian to evaluate the growth and transformation of the traditions that coalesce in the canonical twenty-seven books. We have glimpses of these historical processes in the New Testament books themselves, as their authors and characters

\footnotetext{
${ }^{48}$ Ratzinger, "The Question of the Concept of Tradition," 60.

${ }^{49}$ Ratzinger, "The Question of the Concept of Tradition," 61.

${ }^{50}$ Ratzinger, "The Question of the Concept of Tradition," 61. Such is true, of course, only on the revisionary terms of the Christian reader. Jewish readers will not concur but are no less competent as readers.
} 
seek a "new understanding of the old in a new situation" gospel and kingdom proclaimed by Christ.

Finally, the ultimate horizon of Christian reading of biblical tradition is "an ecclesial theology of the New Testament" which, for Ratzinger, is synonymous with dogmatics. ${ }^{52}$ This layer finds its counterpart in the second layer, the "New Testament theology of the Old Testament," which rereads the Old in light of the New. In this fourth layer the past is similarly read in light of the present, but, in this case, it is not Israel's scriptures in light of Christ, but the Christian scriptures in light of the church. If we recall Gregory's “order of theology," this is the era inaugurated by the third earthquake, "the present shaking" which involves the reinterpretation of Jesus's announcement of the kingdom in light of the ecclesial reception of the Spirit. As is the case with the "New Testament theology of the Old Testament," the "ecclesial theology of the New Testament" is not "exterior" to the New Testament. Rather, "within the New Testament itself, begins the ecclesial process of interpreting what has been handed down."53 Ratzinger points to the complex redactional history of the synoptic tradition as one clear instance of how an ecclesial theology of the New Testament is internal to the New Testament itself, as tradition appropriates and reinterprets prior traditions from the perspective of new ecclesial circumstances. Hence, in Ratzinger's view, the New Testament both canonizes subsequent self-interpretations of its own contents and also authorizes its own ongoing reinterpretation in light of changing ecclesial conditions, as the fourfold Gospel tradition itself teaches us to do.

\footnotetext{
${ }^{51}$ Ratzinger, "The Question of the Concept of Tradition," 61.

${ }^{52}$ Ratzinger, "The Question of the Concept of Tradition," 61.

${ }^{53}$ Ratzinger, "The Question of the Concept of Tradition," 61.
} 


\section{Conclusion: Scripture, Dogma, and Ecclesial Senses of the New Testament}

There is much to commend in Ratzinger's systemization of the Christian scriptural traditions and also issues with which to quibble. Ratzinger knew this, noting that "the scheme thus outlined represents in the first instance only a rough draft that would need many clarifications and distinctions in detail to be regarded as exact." 54 To conclude, I would like to attempt something of a partial second draft of Ratzinger's rough draft, but one specifically focused on the relation of ongoing theological formulations to the New Testament and its "ecclesial interpretation" within and for the church today. I return to the association of ecclesial interpretation of the New Testament with New Testament interpretation of the Old Testament. To do this, I refer to a recent exchange between Richard Hays and David Ford on Hays's deservedly celebrated Echoes of Scripture in the Gospels.

Hays contends that the Gospel writers creatively reinterpreted the Old Testament from the perspective of new facts. Something surprising had happened in their world, and that revelation transfigured their perceptions of what the prior revelation found in ancient Judean writings must mean. The Gospel writers thus occupied a space of epistemological crisis where is (present reality) and ought (prior or conventional expectations) collided. In the words of Rowan Williams, "Christian faith has its beginnings in an experience of profound contradictoriness, an experience which so questioned the religious categories of its time that the resulting reorganization of religious language was a centuries-long task." ${ }^{55}$ That "reorganization of religious language" is what Hays refers to as figural reading of the Old

\footnotetext{
${ }^{54}$ Ratzinger, "The Question of the Concept of Tradition," 62.

${ }^{55}$ Rowan Williams, The Wound of Knowledge: A Theological History from the New Testament to Luther and St. John of the Cross (Eugene, OR: Wipf \& Stock, 1998), 1. See the use of this quotation in Hays, Echoes of Scripture in the Gospels, 4, 105, 187, and 348.
} 
Testament - an accounting of how is and ought now rhyme. I have referred to this as allegory, but terms need not trouble us. What we are both trying to identify is the revisionary and retrospective ("reading backwards") appropriation of Jewish scripture in light of the advent of Christ. This is Gregory's second earthquake and Ratzinger's New Testament theology of the Old.

In his review of Hays's book, David Ford presses how Hays's hermeneutical insights regarding New Testament reading of the Old might apply to ongoing readers of the New. Focusing on the Gospel of John, Ford submits that “John's daring interpretations of his own Scriptures should therefore inspire daring interpretations of his Gospel as we, like him, are led 'into all truth'." ${ }^{56}$ As Ford notes, the key to Hays's figural hermeneutic is the temporal relation of text and reader and the readerly commitment to reading the text as still revelatory for the present. This allows the reader to discern "unexpected patterns of correspondence between earlier and later events or persons within a continuous temporal stream." 57 The present experience of the reader thereby refracts and transforms the scriptural text as it is drawn into figural correspondence with the present. In the previous sentences, "reader" refers to the Evangelists as interpreters of the Old Testament. But subsequent readers of those "readers" are also readers, and readers of a scriptural text named New Testament. To read the New Testament as relevant for today will also involve discovering "unexpected patterns of correspondence between earlier and later events or persons within a continuous temporal stream." ${ }^{58}$ Our present experience will similarly refract the New Testament as it is

\footnotetext{
${ }^{56}$ David F. Ford, "Reading Backwards, Reading Forwards, and Abiding: Reading John in the Spirit Now," Journal of Theological Interpretation 11 (2017): 69-84, here 70.

${ }^{57}$ Ford, "Reading Backwards," 70.

${ }^{58}$ Ford, "Reading Backwards," 72.
} 
apprehended in relation to our present. Ford refers to this as a "Spirit-led 'reading forwards"' into the life of the church. ${ }^{59}$ For Ford, "Simply trying to repeat what John said and thought is not Johannine." 60 The question for us, then, is "What fresh, transformative theological syntheses should we be shaping as we reread not only John and the rest of Scripture but also the theology that has been produced down the centuries and around the word?"61

In his reply to Ford, Hays places additional stress on the need to "read forward" from the person of Jesus and into the life of the church:

There can be little doubt that Ford has put his finger on a major, and often surprisingly overlooked, feature of John's narration: John models a rhetoric of superabundance and beckons his readers to "read forwards" to understand much more about Jesus than what Jesus himself taught them during his earthly life, or even more than what John has written. I think Ford is correct to argue that John therefore represents an open-ended hermeneutic that regards simple repetition of the canonical texts to be actually unfaithful: the community guided by John's wisdom must always be open to fresh guidance from the Spirit-Paraclete who guides us into deeper apprehension of the truth, a truth that is always centered and grounded in Jesus as the revelation of God, Jesus as the Word. ${ }^{62}$

Hays is surely correct that the Johannine imperative "to understand much more about Jesus than what Jesus himself taught" is indeed significant, but even if this is "often surprisingly

\footnotetext{
${ }^{59}$ Ford, "Reading Backwards," 70.

${ }^{60}$ Ford, "Reading Backwards," 82.

${ }^{61}$ Ford, "Reading Backwards," 82.

${ }^{62}$ Richard B. Hays, "Continuing to Read Scripture with the Evangelists: A Response,"
} Journal of Theological Interpretation 11 (2017): 85-99, here 94. 
overlooked," it has not failed to transpire. Understanding more about Jesus than what Jesus himself taught is, like the intellectual unfolding of any luminous idea, precisely what theological reflection aspires to learn. And, according to John, Jesus himself, via the Spirit of Truth, empowers this unfolding (John 16:7-13).

In the conclusion to Echoes of Scripture in the Gospels, Hays describes the Evangelists's "act of understanding" the Old Testament in terms of its figural relation to Christ as an intellectus spiritualis, a spiritual understanding, and he again underscores its retrospective orientation: "A figural christological reading of the Old Testament is possible only retrospectively in light of Jesus' life, death, and resurrection. Thus, from the perspective of figural interpretation, it would be an unwarranted hermeneutical presumption to read the Law and the Prophets as deliberately predicting events in the life of Jesus." ${ }^{\prime 63}$ A similar retrospective dynamic is at work in ongoing ecclesial interpretation of the New Testament and, as Gregory of Nazianzus has taught us, the same intellectus spiritualis is required. Ecclesial interpretation of the New Testament does not presume that John or Paul or any other New Testament author had a developed (capital-T) Trinitarianism. But it does presume that interpretive developments - developments "penetrating the letter and peering into the inner meaning" of New Testament witness (Or. 31.21) —will cohere with patterns of judgment in the likes of John and Paul, and that, in turn, these developments will reillumine the New Testament texts themselves. This feedback loop is the hermeneutical power of ecclesially located theological interpretation.

Historically and theologically, the New Testament canon and its ecclesial interpretation are intertwined and mutually determinative. To read the New Testament as New Testament (and not a sample of documents from the history of early Christianity) is

${ }^{63}$ Hays, Echoes of Scripture in the Gospels, 348. 
already to be wrapped up in a theological act. The New Testament canon is authorized by dogmatic determination. Creed corroborates canon, which corroborates creed. For historical and theological reasons, historians and theologians will vary in their assessment of the integrity of this open-ended, ever expanding circularity. Prejudices (or, if you like, traditioned plausibility structures) will dictate the confidence one places in creed, canon, and tradition. Questions about distortion and historical amnesia will persist. Argument about what counts as "tradition," and what authorizes its revision, must persist - the conservative and creative impulses within a tradition are the coronary circulation that keep it alive. Counterfactual canons may certainly be concocted and debated ${ }^{64}$ But, as Robert Jenson remarks, "A different history might have shaped a different canon, but since history contrary to fact is imponderable, so is that canon." ${ }^{65}$ So it is of ecclesial interpretation: A different history might have shaped different dogmatic determinations, but since history contrary to fact is imponderable, so is that dogma. Dogma illumines scripture, which illumines dogma. This, too, is the order of Christian theology.

${ }^{64}$ For incisive reflection on counterfactual canons, see R.W.L Moberly, "Canon and Religious Truth: An Appraisal of A New New Testament," in When Texts are Canonized, ed. Timothy H. Lim with Kengo Akiyama, Brown Judaic Studies 359 (Providence, RI: Brown University, 2017), 108-35.

${ }^{65}$ Robert W. Jenson, Canon and Creed (Louisville, KY: Westminster/John Knox Press, 2010), 41. 